\title{
V. On a Collection of Fungi made by Mr. Sulpiz Kurz, Curator of the Botanic Garden, Calcutta. By Frederick Currey, M.A., F.R.S., Sec.L.S.
}

(Plates 19-21.)

Read June 4th, 1874.

THE fungi to which this paper relates were collected mostly in Pegu by Mr. Sulpiz Kurz, Curator of the Botanic Garden at Calcutta. I am not aware that any collections of fungi have heretofore been made in Pegu, and an interest therefore attaches to the present one as being so far the first of its kind. As might be expected, many wellknown tropical forms occur. There are several species, especially amongst the Polyporei, which, although previously described, are by no means well known; and it will be seen that there are some new forms of considerable interest. In the examination of the plants I have had the advantage of access to Mr. Berkeley's valuable herbarium, for which, and for his kind assistance in the determination of some of the species, I am desirous of expressing my acknowledgments.

\section{AGARICINI.}

Several species of Agaricus accompanied the other fungi; but it is hopeless to attempt to name specimens of this genus unless they are accompanied by coloured drawings of the fresh plant, careful sectional figures, and notes of the colour and shape of the spores. Micrometric measurements of the spores should be added in all cases where practicable. Amongst the specimens were some which appeared to belong to Ag. silvaticus, Fr., and Ag. fimicola, Bolt., and others which were identical with or allied to Ag. spadiceus, Fr., and Ag.picreus, Fr. Others, belonging to the subgenera Lepiota, Tricholoma, Volvaria, Psathyra, and Psathyrella, were not further determinable. One small Agaric is noted as being used for food. It resembles Ag. semiorbicularis, Bull.; but that plant is not edible. Two species of Marasmius occur, one of which has not dried well: the other (No. 3472), in the dried state, is just like M. ramealis, Fr.; but Mr. Kurz describes it as white when fresh, so that it can hardly be that species.

Lentinus capronatus, Fr. Epicrisis, p. 390 ; Persoon in Freycinet's Voyage, t. 2. f. 3.Myodwine, Evergreen Forests, Pegu. No. 2604.

This is an interesting series of specimens, varying in the size of the pileus from $\frac{3}{4}$ inch to $1 \frac{1}{2}$ inch. In three of the plants the pileus is distinctly zoned. The gills cannot be called denticulate, although some are very slightly uneven at the edge. The figure in 'Freycinet's Voyage' is very good, but the specimens there represented are small.

L. Descendens, Fr. Epicr. p. 390.-Tonkyeghat, Pegu, Evergreen Forests. No. 2629.

This species was found by Afzelius in Guinea, in gravelly soil. It is figured by him in SECOND SERIES.-BOTANY, VOL. I. 
the 'Fungi Guineenses,' t. x. fig. 22. The specimen is in bad condition, and I have some doubts about the species.

Lentinds furfurosus, Fr. Epicr. p. 391.-Yomah, Pegu. No. 3474*.

L. velutinus, Fr. Epicr. p. 392.-Yomah, Pegu. No. 3498.

L. glabratus, Mont. Cuba, p. 424. No. 1779.-North Rajmehal hills, N. Bengal.

There are but two specimens of this species, and they have not been very successfully dried. The margin of the pileus can hardly be called hairy; but in all other respects the plant agrees with $L$. glabratus.

L. SaJor CaJU, Fr. Epicr. p. 393. Rumph. Amb. t. 56. f. 1.-South Andaman. Nos. $2560,2561$.

"Sajor Caju" is the Malay name of the plant.

L. Exilıs, Fr. Epicr. p. 393.-Tonkyeghat, Nakawa, Evergreen Forests, Pegu. No. 2592. Sittang valley, Pegu. Nos. $3487 \& 3488$.

L. Inquinans, Berk., Hooker's Journal of Botany, 3rd series, vol. iv. p. 130, t. vii. f. 1.Kemendine, Jack Tree Gardens, near Rangoon, Pegu. No. 2600.

I think there is no doubt about the species, although the single specimen gathered by Mr. Kurz varies from the type in some particulars. The gills are somewhat narrower, and the warts and the brown pubescence of the pileus have rubbed off in drying; but there are dark spots all over the pileus, showing the places where the warts were attached. The bristles have disappeared, except here and there at a short distance from the margin, where they are still plainly visible under a lens, and the transverse scales on the stem are not now to be seen. The latter, however, like the warts, may have been rubbed off in drying. Mr. Berkeley has noticed that in some dried specinens a pellicle separates from the umbilicus, carrying the warts with it and leaving the pileus smooth.

L. Kurzianus, n. sp. Pileo lento, infundibuliformi, furfuraceo-squamuloso, fusco ; stipite brevi, fusco-ferrugineo, ad basin nigricante; lamellis profunde decurrentibus, læte rubiginosis.-Yomah range, Pegu. No. 3497.

This is a beautiful species, in many points resembling $L$. furfurosus, Fr., from which it differs in the deeply funnel-shaped pileus and in the colour of its gills. In L. furfurosus the mycelium (held together by the sand in which it grows) forms an indurated tuberiform root. In the specimens of the present species the stipes has the appearance of having been broken off in gathering; so that it is not improbable that a tuberoid radix may be present in the perfect state, which would bring the plant still nearer to $L$. furfurosus, Fr. The colour of the gills varies from a bright rust-colour to a greyish brown, according to the incidence of the light under which they are examined.

Plate 20. fig. 11. Plant, natural size.

L. CAspitosus, n. sp. Dense cæspitosus. Pileo infundibuliformi, squamis subconcentricis ornato; stipite versus basin attenuato; lamellis substipatis, decurrentibus, (siccis) brunneis.-Pegu. No. 2624. No special locality is given.

* In the specimens of this species the stems have been broken off short in gathering, so that there is no tuberiform radix, and the gills are too dark-coloured to be described as " flavidis ;" but the plant comes so near in other respects to $L$. furfurosus, Fr., that $I$ do not venture to propose it as a new species. 
I find no species described which agrees with this. The plant is stated to be white when fresh. In the dried state it is of a brownish fawn-colour, the gills being somewhat darker than the pileus.

Plate 19. figs. 4 and 5. Fig. 4, a group of plants, natural size; fig. 5, a single plant.

Lentinus Irregularis, n. sp. Pileo (sicco) nigricante, fragili, infundibuliformi; lamellis cinnamomeis, irregularibus, hic per totum stipitem decurrentibus, illic annulatim abruptis.-Karen country. Pine-forests from Theemeechu to Borkee. No. 2534.

There are four specimens of this species, in two of which the gills run down the whole length of the stem, whilst in the other two they terminate abruptly, and break off in a way very similar to what is seen in the British species $L$. fimbriatus, Curr. If the two latter specimens only had been examined, I should probably have referred them to L. fimbriatus.

Plate 19. figs. 14 and 15. Plants, natural size.

Schizophyllum commune, Fr. Several specimens of this species occur in Mr. Kurz's collection.-The localities are:-Botanic Garden, Calcutta, Nos. 1781 and 2649; Ross Island, South Andaman, No. 2562; Sikkim Himalaya, Nos. 2572 and 2575; Tonkyeghat, Pegu, No. 2598.

Lenzites albida, Fr. Epicr. p. 405.--Tonkyeghat, Pegu. No. 2601.

I have seen no specimens of $L$. albida, Fr. No. 2601 agrees with the description in the 'Epicrisis,' except in being stipitate and in the gills having a cinnamon-colour. Nothing is said by Fries as to the size of L. albida. The pileus in the present plant measures $\frac{7}{8}$ of an inch by $\frac{5}{8}$ of an inch, and at first sight much resembles Pamus stypticus, Fr.; but the anastomosing gills show that it cannot be that species.

L. Palisoti, Fr. Epicr. p. 404.--Seven Pagodas, Evergreen Forests, Tonkyeghat, Pegu. No. 2590 .

There is another specimen in the collection (No. 2604), which seems to be the same species, from the Botanic Garden, Calcutta.

\section{POLYPOREI, Fr.}

Polyporus (Mesopus) perennis, Fr. Epicr. 434; ib. Hym. Eur. 531.

Sent by Dr. Stoliczka from Penang. No. 2041.

P. (Mesopus) xanthopus, Fr. Epicr. 437.-Pegu, Nakawa, Evergreen Forests, Tonkyeghat, No. 2533; Sittang valley, Pegu, No. 3489; Yomah range, Pegu, No. 2627.

There is also a specimen from South Andaman, No. 2563.

P. (Mesopus) Florideus, Berk., Hooker's Journal of Botany, 3rd series, vol. vi. p. 137.Pegu, Karen country, Bookee ridges, 5000-6000 feet, Pine-forests, No. 2595.

This species was found by Dr. Hooker at Darjeeling, at a height of 7500 feet.

P. (Mesopus) Hypoplastus, Berk., Hooker's Journal of Botany, vol. viii. p. 174.-Howrah district. On bamboo. No. 2652.

This species was first found by Mr. Spruce at Panuré. Mr. Berkeley has noticed that the pileus is sometimes lateral; and this is the case with three out of the four specimens sent by Mr. Kurz. Judging from Mr. Kurz's specimens alone I should have placed the plant in the division Pleuropus. 
Polyporus (Apus, Placodermei) cinereo-fuscus, n. sp. Pileo dimidiato, lignoso, durissimo, margine tenui, basin versus incrassato, fusco-cinereo, rugoso-tuberculoso; poris minimis, cinereo-fuscis.

Pileus $1 \frac{1}{2}-2$ inches wide, of a dull brown colour, with blotches of black, thin at the margin but thickening rapidly towards the base, longitudinally rugose with tubercles; pores very minute, blackish brown, sometimes almost quite black.-Pegu, Nakawa, Evergreen Forests, Tonkyeghat. No. 2606.

Mr. Berkeley was inclined to refer this plant to his Polyporus ferreus (London Journ. Bot. vol. vi. p. 502. no. 175); but it differs from that species in its dark pores and in some other characters. It is allied to P. fasciatus and P. supinus of Swartz.

Plate 19. fig. 1. Plant, natural size.

P. (Inodermei) cinnabarinus, Fr. Epicr. p. 473.-On old logs, Botanic Garden, Calcutta. No. 2681.

P. (Inodermei) scruposus, Fr. Epicr. p. 473.-Martaban Hills, Shan toung gyre toung, 3800 feet. No. 3492.

P. (Inodermei) Feei, Fr. Epicr. p. 476.-Pegu, Yomah. No. 3493.

P. (Inodermei) versicolor, Fr. Epicr. p. 478.-Sikkim Himalaya, 7000 feet, on dead wood. No. 2567.

P. (Inodermei) pinsitus, Fr. Epicr. p. 479.-Nattoung ridges, Karen country, 6000 feet. No. 2608.

A. (Inodermei) cinerascens, Fr. Epicr. p. 481.-Yomah, Northern Pegu. No. 2609.

Fries describes the pileus in his $P$. cinerascens as fuscous, and the pores as cinereous. In Mr. Kurz's plant the pileus is rather ochraceous than fuscous, and the pores are reddish brown. These differences in colour are hardly sufficient to separate it as a species.

P. (Inodermei) Anebus, Berk. Lond. Journ. Bot. vol. vi. p. 504.-Tonkyeghat, Pellowa, Evergreen Forests, Pegu. No. 2599.

This is a small thin form of Mr. Berkeley's species. From Mr. Berkeley's remarks (loc. cit.) it seems to be a variable plant.

P. (Inodermei) xerophyllaceus, Berk., Hook. Journ. Bot. 3rd series, vol. viii. p. 200.

No. 2658.-Botanic Garden, Calcutta, on old logs in the rainy season.

Mr. Kurz's specimens agree very well with Mr. Berkeley's description. In some the pilei are confluent laterally, in others imbricated. I should rather have placed the plant in the "Anodermei," but have retained Mr. Berkeley's division.

Plate 20. figs. 1 and 2. Plants, natural size.

Trametes lobatus, Berk., Hook. Journ. Bot. 3rd series, vol. iii. p. 84.-N. Bengal, Sikkim Terai, on old logs. No. 2569.

T. umbrinus, n. sp. Pileo resupinato, effuso-reflexo, lobato, subtomentoso, leviter zonato ; poris amplis, dentato-laceris. No. 2611.-Pegu, Nakawa, Evergreen Forests, Tonkyeghat.

Plate 21. fig. 4. Plants, natural size.

It is difficult to say whether the larger specimen is a single plant or a mass of 
confluent pilei. The pores underneath the slightly reflexed marginal lobes are at right angles with the pileus. In the centre the pores become elongated and decurrent, overlapping one another in an imbricated manner.

Trametes occidentalis, Fr. Epicr. - Botanic Garden, Calcutta. On old logs in the rainy season. No. 2656.

I have had a little doubt about this species, as the pileus is not "effuso-reflexed," which is one of the characters of $T$. occidentalis. In Mr. Kurz's specimens the pilei are dimidiate. Substituting " dimidiato-" for " effuso-reflexo" in Fries's description, the latter applies exactly to Mr. Kurz's plant.

T. cingulatus, Berk., Hook. Journ. Bot. 3rd series, vol. vi. p. 164.-Pegu, Yomah. No. 3475 .

Other specimens in Mr. Kurz's collection from the Botanic Garden, Calcutta (Nos. $2679 \& 2685$ ), show that this species varies a good deal in the thickness and in the pubescence of the pileus, the latter being sometimes silky, sometimes woolly in its appearance. The pubescence, of whichever kind, is always slight, a lens being almost necessary to see it distinctly.

\section{DeDalea.}

Dedalea tenuis, Berk.-Pegu, Yomah. No. 2603.

Another specimen of this species from South Andaman Island occurs in Mr. Kurz's collection.

D. Discolor, Fries, Epicr. p. 494.-Pegu, Yomah. No. 3503.

D. zonata, Fr: Epicr. p. 494.-Pellowa, Evergreen Forests, Tonkyeghat, Pegu. No. 2589.

I have not seen specimens of Fries's $D$. zonata. The present plant only differs from Fries's description in the pileus being wrinkled and very slightly pubescent, characters which hardly justify its being made a new species. I should place it under $D$. zonata as var. rugoso-pubescens.

\section{Hexagonia, Fr.}

Hexagonia polygramma, Mont. Fr. Epicr. p. 497; Mont. Sylloge, p. 169; Cuba Crypt. (Ramon de la Sagra), p. 379, t. 14. f. 3.-Pellowa, Evergreen Forests, Tonkyeghat, Pegu. No. 2597.

H. Tenuis, Fr. Epicr. p. 498.-Pegu, Elephant Point. On old trees along the shore. No. 3484 .

This is exactly the plant of Fries, agreeing in every particular. There are two other forms (both from Yomah) in the collection (Nos. 3494 \& 3505), which I cannot satisfactorily separate from $H$. tenuis. No. 3494 differs in having a darker-coloured pileus and smaller pores, the latter being brown, without the grey tinge of the pores of H. tenuis. In No. 3505 the pileus and pores are precisely similar in colour to those of No. 3494, but are a good deal larger. 
Hexagonia Kurzi, n. sp. Pileo coriaceo, glabro, orbiculato aut reniformi aut dimidiato, corrugato, zonato, rubro-fusco ; alveolis amplis, intus canescenti-fuscis, acie cinnamomea.-Mutlah. No. 2028.

Plate 20. figs. 3, 4, and 7. Figs. 3 and 7 , the upper side; fig. 4, the under side of different plants : natural size.

This species comes very near to H. nitida, D.R. et M. It differs in having the pileus sometimes quite circular, and in the colour of the pores, which are of a pale bright grey in the inside, with the edge of a distinctly cinnamon-colour.

\section{HYDNEI.}

Hydnum udum, Fr. Epicr. p. 517-Mutlah, Calcutta. No. 2030.

Tremellodon gelatinosum, Fr. Hymenomycetes Europæi, p. 618.--Sikkim, 7000-8000 feet. No. 2573.

Tremellodon is a genus formed by Fries to include Hydnum gelatinosum, Scop., and $H$. auriculatum, Fr. These plants have the aculeate hymenium of Hydnum, but the fructification of Tremella. See Linn. Journ. vol. v. p. 181.

IrPex flavus, Kl. ; Fries, Epicr. p. 522.-Arracan, Baronga Islands, on old wood, 1000 feet. No. 2047.

I. Pallescens, Fr. Epicr. p. 522.-Yomah, Pegu. No. 3495.

There is one other Irpex in the collection (No. 3486) from the Sittang valley, Pegu. It has been partially destroyed by insects, and is not certainly determinable; but it must, I think, be either I. flavus, or I. sinuosus, Fr.

Grandinia granulosa, Fr. Epicr. p. 527.-Pellowa, Evergreen Forests, Tonkyeghat, Pegu. No. 2594.

\section{AURICULARINI.}

Thelephora pusilla, n. sp. Pusilla, fuscescens, simplex vel ramosa, sursum cristatodivisa.-Sikkim Himalaya, 2000-2500 feet. No. 2570.

This species is evidently allied to T. cristatella, B. \& Br. (a Ceylon plant), but it differs in the colour, which varies from light to dark brown, and in the divisions, which are rather clavate than acute.

Plate 21. fig. 9. Plants, natural size.

T. Palmata, Fr. Epicr. p. 537.-Botanic Garden, Caleutta. On bamboo-trunks. No. 2661. Stereum elegans, Fr. Epicr. p. 543.- In bamboo-jungles, but the locality is not given. No. 1792. Lower Pegu, junction of Pegu river and Khayasoo Choung. No. 2631.

The specimens under the latter number are very small, but there is no doubt about the species.

S. ostrea, Fr. Epicr. 547.-Sikkim Himalaya, 4000-6000 feet. No. 2579.

S. LobatuM, Fr. Epicr. p. 547.-Pegu, Tonkyeghat, the seven Pagodas. No. 2596.

In Mr. Kurz's collection there is another specimen of S. lobatum (No. 2564), from Escape Bay, South Andaman Island. 
Stereum scytale, Berk., Hook. Journ. Bot. 3rd series, vol. vi. p. 170.-Pegu, Karen Hills, Bookee ridges, 5000-6000 feet. No. 2618. Pegu, Yomah. No. 3504.

Plate 19. figs. 8, 9, and 10. Fig. 8, the under side; figs. 9 and 10, the upper side of different plants: natural size.

This species was found by Drs. Hooker and Thomson in the Khasia mountains, and by Capt. (now General) Strachey in the Western Himalayas.

S. ADUSTUM, Lev. Ann. d. Sc. Nat. (1844), 3rd series, vol. ii. p. 213.-Southern Yomah, Pegu. No. 2602.

This is more properly a Hymenochete.

S. Papyrindm, Mont. Sylloge, p. 178.-Pegu, Timeokee, Evergreen Forests. No. 2623.

S. MEDICUM, n. sp. Effusum, resupinatum, tenuissimum, margine subhirsuto; hymenio inæquali in prominentiis rotundis elevato, fusco-tabacino, subvelutino.-Sikkim, 5000-6000 feet. No. 2582.

This is a very curious production: the pileus is very thin, but the plants grow together in a stratified mass, the mass having exactly the appearance of being composed of thin layers of tobacco. It is used by the Lepchas in medicine, and has a native name.

Plate 20. figs. 9 and 10. Fig. 9, a portion (about half) of a plant; fig. 10, a section : natural size.

S. CYathiforme, n. sp. Cyathiforme, extrinsecus hirsutum, margine inflexo; hymenio lævi ad marginem cyathi pallide umbrino, basin versus rubro-fusco.-Pegu, Karen Hills, Bookee ridges, 5000-6000 feet. No. 2619.

Plate 21. fig. 1. Plants, natural size.

This is a very pretty plant, looking like a Crucibulum without sporangia.

Corticium violaceo-Lividum, Fr. Epicr. p. 564.--Pegu, Yomah. No. 3476.

C. Levigatum, Fr. Epicr. p. 565.-Pegu, Yomah. No. 3507.

C. Movgeotim, Fr. Epicr. p. 558.-Sikkim Himalaya, Phalloot, on dead trees, 11,00012,000 feet. No. 2571.

Guepinia ramosa, n. sp. Cæespitosa, simplex vel ramosa; ramis apice bifurcatis vel cristatis; hymenio aurantiaco ; stipite subtus cinerascente.--Arracan, Kolodyne valley, on old wood. No. 2044. Howrah district, on old logs. No. 2640.

Plate 21. figs. 2 and 3. Plants, natural size.

Varying from $\frac{1}{4}$ to 1 inch in height, and from the simple forms of fig. 3 to the ramose state of fig. 2 .

\section{CLAVARIEI.}

Calocera viscosa, Fr. Epicr. p. 581.-Seebpore, Lower Bengal. No. 2196. Typhula fuscipes, Fr. Epicr. p. 586.

A specimen of this species occurs with No. 2567 (Polyporus versicolor).

\section{TREMELLINI.}

Tremella foliacea, P. Fr. Syst. Myc. vol. ii. p. 212.-Sikkim Himalaya, on shrubs, 10,000 feet. No. 2580 . 
Hinneola Auricula Jude, Fr. Hym. Eur. p. 695.-Nakawa, Evergreen Forests, Tonkyeghat. No. 2591.

H. AUricula Canis, Fr. Syst. Myc. vol. ii. p. 222 (sub Exidia).-Pegu, Northern Yomah, on logs. No. 2615.

\section{NIDULARIACEI.}

Cyathus intermedius, Mont. Sylloge, p. 284.-Seebpore, Lower Bengal. No. 2198.

This plant agrees very well with Montagne's species, but it is not striate within. I do not observe the blackness in the substance of the sporangia noticed by Montagne; but this feature probably depends upon age.

\section{LYCOPERDACEI.}

Lycoperdon gemmatum, Fr. Syst. Myc. vol. iii. p. 36.-Sikkim Himalaya, 7000-8000 feet. No. 2576.

Spores globose, nearly 0.0002 inch. No. 2581, also from Sikkim Himalaya, 900010,000 feet, and No. 2653, from the Botanic Garden, Calcutta (in bamboo-thickets amongst dead bamboo remains), may be forms of $L$. gemmatum, Fr.; but there are no notes, and dried Lycoperdons are most difficult to determine.

L. Pusillud, Fr. Syst. Myc. vol. iii. p. 33.-Lower Pegu, Kayosoo Choung, in elephantgrass jungles. No. 2630.

L. BRasiLiense, Fr. Syst. Myc. vol. iii. p. 40.-Pegu, Nakawa, Evergreen Forests, Tonkyeghat. No. 2635.

The specimens are, unfortunately, in very imperfect condition; but the peridium is membranous and punctate, the flocei broad and lax, and it grows on wood. It seems to agree sufficiently well with Fries's species. It is accompanied by Hypoxylon marginatum, Schw.

\section{TRICHODERMACEI.}

Trichocoma Paradoxum, Jungh. Sikkim Himalaya, 6000-7000 feet. On mossy dead stems. No. 2585.

\section{MYXOGASTRES.}

Trichia pyriformis, Hoffm. On wood, with No. 2585 (Trichocoma paradoxum). Arcyria umbrina, Fr.-Pellowa, Evergreen Forests, Tonkyeghat, Pegu. No. 2626.

\section{HELVELLACEI.}

Peziza aurantia, Pers. Fr. S. M. ii. p. 49.-Sikkim, great road, on earth. No. 2578.

P. Rutilans, Fr. S. M. ii. p. 68.-Junction of the Choungmenal Choung and Tonkyeghat rivers. On mud banks. No. 2587.

Helotidm citrinum, Fr. Peziza citrina, Fr. S. M. ii. p. 131.-Sikkim Himalaya, 50007000 feet. On rotten wood. No. 2583. 


\section{SPOROCYBACEI.}

Stilbum Inconspicudm, n. sp. Solitarium vel cæspitosum, minutissimum; capitulo subgloboso, albido ; stipite badio, deorsum leviter incrassato ; sporis ellipticis, nucleo excentrico ornatis, 0.0002 unc. longis.-Seebpore, Lower Bengal. No. 2197.

S. ERYThocephalum, Dittm. var.-On dead bamboo-stems, Botanic Garden, Calcutta, rainy season. No. 2639.

This plant hardly differs from S. erythrocephalum, Dittm.; but the stem is only very delicately pilose, with silky adpressed hairs.

\section{SPHÆRIACEI.}

Xrlaria digitata, Grev. Spharia digitata, Fr. S. M. ii. p. 326.-Botanic Garden, Calcutta. On moist logs. No. 1791.

X. тавасina, Kickx.-Sikkim Himalaya, 7000-8000 feet. On old fallen trees. No. 2575.

X. GuYanensis, Mont. Sylloge, p. 202.-Tonkyeghat, Evergreen Forests, Pegu. No. 2625.

X. POLYMonpha, Grev. Spheria polymorpha, Fr. S. M. ii. p. 326.-Botanic Garden, Calcutta. On old logs in the shade, rainy season. No. 2659.

X. HYPoxylon, Grev. Spharia hypoxylon, Fr. S. M. ii. p. 327.-Arracan, Baronga Island, on old tree-stumps. No. 2046. Botanic Garden, Calcutta, on old logs, rainy season. No. 2657.

X. Kurziana, n. sp. Solitaria vel cæspitosa, vel etiam connata, $\frac{1}{4}-1$ unc. longa; capite castaneo subhemisphærico, peritheciis prominentibus scabro; sporidiis nigro-fuscis, amygdaloideis, 0.0006-0.0007 unc. longis.-On brick-laid paths where fire had been burnt. Botanic Garden, Calcutta, rainy season. No. 2650.

Plate 21. fig. 8. Plants, natural size.

The dried plants required to be moistened to bring out the colour, which is a chestnutbrown. Mr. Kurz describes them as yellow at first and then brown. There is another Xylaria in the collection (No. 1783, from the Calcutta Botanic Garden), which seems to be the same as No. 2650. The habitat, viz. brick-laid soil upon which fires had been burnt, is somewhat peculiar for a Xylaria.

X. Flagelliformis, n. sp. Solitaria vel cæspitosa, simplex vel furcata, flagelliformis, colore carneo; peritheciis _ ? - On earth, Sittang valley, along the base of the Yomah range, Pegu. No. 3485.

Plate 21. fig. 5. Plants, natural size.

X. mutabilis, n. sp. Solitaria vel cæspitosa vel connata, simplex vel ramosa, vel cristata; stipite nigro, rugoso, interdum profunde sepulto; capite elongato, vegetante carneo, sicco pallide umbrino, ostiolis nigris prominentibus scabro; sporidiis uniseriatis, nigro-fuscis, irregularibus (reniformibus, subellipticis vel subglobosis), minutissimis, vix 0.0001 unciæ attinentibus.-On brick-laid paths in the Botanic Garden, Calcutta. Very common in the rainy season. No. 1790.

Plate 21. figs. 10 and 11. Plants in different states, natural size.

This plant is remarkable for its irregular growth, the small size of its sporidia, and the 
densely crowded state of the asci, which are often difficult to distinguish. I do not know any species of Xylaria with similar fructification.

Hypoxylon suborbiculare, Welw. \& Curr. Trans. Linn. Soc. vol. xxvi.p. 281.-On old $\operatorname{logs}$, Botanic Garden, Calcutta. No. 1809.

Mr. Kurz's specimens exhibit in section a browner and more corky substance than the typical H. suborbiculare; but I see no reason to doubt the identity of the plants. The difference is probably due to age.

H. concentricum, Bolt. On old wood, Botanic Garden, Calcutta. No. 1810.

H. marginatum, Schw. This species occurs (as above mentioned) upon the wood to which Lycoperdon brasiliense was attached.

Diatrype Rugosa, n. sp. Irregularis; stromate rugoso vel depresso et marginato, intra et extra nigro; peritheciis in stromate sepultis, plus minus biserialibus; sporidiis irregularibus, globosis, ellipticis vel pyriformibus, $0 \cdot 0005-0 \cdot 0006$ unc. longis.

On hard wood. Yomah, Pegu. No. 3471.

The stroma in this species occurs in minute rounded patches, sometimes it is prominent and rugose, sometimes depressed, with a margin, and then (under a lens) looking very like a Patellaria.

Hrpocrea variabilis, n. sp. Statu juniore placentiformis, disco vel umbone concentrico ornata, colore citrino; statu adulto subglobosa vel irregularis, rugosa, colore umbrino ; sporidiis

Hab. On living leaves of bamboo, Yomah, Pegu. No. 3480.

Plate 21. figs. 6 and 7. Fig. 6, part of a leaf with plants, natural size; fig. 7, a plant, magnified.

Spheria phaselina, Mont. Sylloge, p. 239.

Hab. Nakawa, Evergreen Forests, Tonkyeghat, Pegu.

S. sublimbata, D. R. et Mont. Fl. Alg. p. 498; Sylloge, p. 228.

Apparently on stems of Thysanolena acarifera, Kambala toung, top.

Micropeltis applanata, Mont. Sylloge, p. 245.

On Girroniera leaves, Mangrove Bay, South Andaman Island. No. 2565.

Fumago salicina, Tul. Sel. Fung. Carp. vol. ii. p. 280.

On Sphenodesma erycibordes, Pz., Wa-choung, Yomah, Pegu. No. 3482.

Nectria Eugenie, n. sp. Peritheciis pallide citrinis, tomentosis, in stromate concolori collocatis vel ejusdem marginem amplectentibus; sporidiis _-?

On dead leaves of Eugenia. Yomah, Pegu. No.3479.

This is a very pretty species. The perithecia for the most part are seated round the base of the stroma, the colour of which is rather darker than that of the perithecia.

Graphiola Phenicis, Poit.-On leaves of Phonix paludosa. Calcutta. No. 1744.

The systematic position of this curious plant has not yet been satisfactorily determined. Some years ago I examined with great care some specimens kindly furnished to me by the late Sir William Hooker, and the results of my observations were published in the Microscopical Journal in 1859 (1st series, vol. vii. p. 225). My conclusions, however, do not coincide with those of Montagne, whose account of the plant is to be found in the 'Annales des Sciences Naturelles,' 4th series, vol. xii. p. 188. 


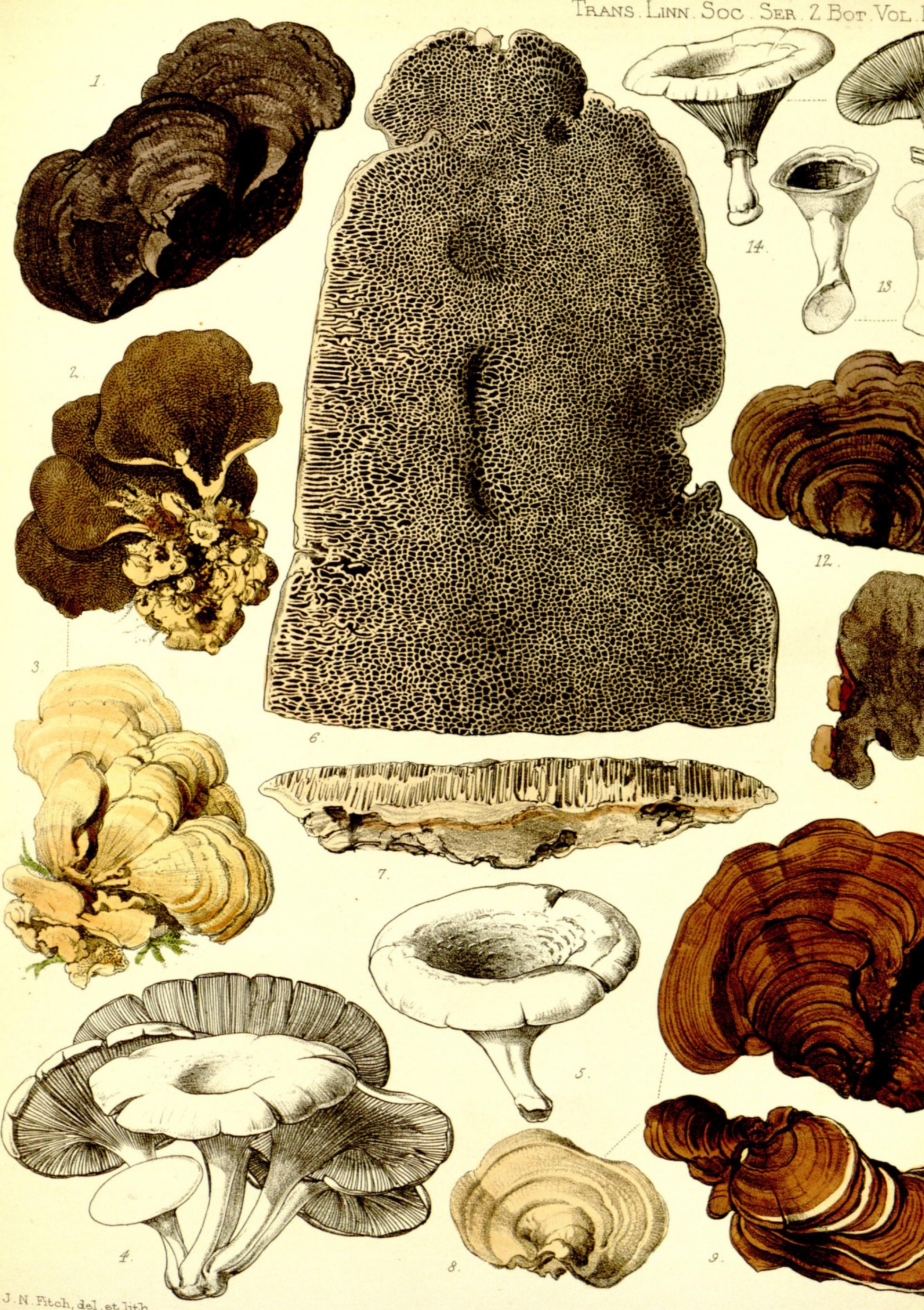




\section{DESCRIPTION OF THE PLATES.}

All the figures except fig. 7, Plate 21, are drawn to the natural size.

\section{Plate 19.}

Fig. 1. Polyporus cinereo-fuscus, n. sp.

Figs. 2 and 3. Polyporus Splitbergeri, Mont. Fig. 2, the under side; fig. 3, the upper side.

Figs. 4 and 5. Lentinus crespitosus, n. sp. Fig. 4, a group of plants; fig. 5, a single plant.

Figs. 6 and 7. Polyporus incertus, n. sp. Fig. 6, a portion (rather more than half) of a plant; fig. 7, a section.

Figs. 8, 9, and 10. Stereum scytale, Berk. Fig. 8, the under side; figs. 9 and 10, the upper side of different plants.

Figs. 11 and 12. Polyporus brunneo-pictus, Berk., var. Fig. 11, the under side; fig. 12, the upper side.

Fig. 13. Polyporus crassipes, n. sp.

Figs. 14. and 15. Lentinus irregularis, n. sp.

\section{Plate 20.}

Figs. 1, 2, and 8. Polyporus xerophyllaceus, Berk.

Figs. 3, 4, and 7. Hexagonia Kurzi, n. sp. Figs. 3 and 7, the upper side; fig. 4, the under side of different plants.

Figs. 5 and 6. Polyporus rubidus, Berk. Fig. 5, upper side; fig. 6, under side.

Figs. 9 and 10. Stereum medicum, n. sp. Fig. 9, a portion (about half) of a plant; fig. 10, a section.

Fig. 11. Lentinus Kurzianus, n. sp.

Plate 21.

Fig. 1. Stereum cyathiforme, n. sp.

Figs. 2 and 3. Guepinia ramosa, n. sp.

Fig. 4. Trametes umbrinus, n. sp.

Fig. 5. Xȳlaria flagelliformis, n. sp. Plants, natural size.

Figs. 6 and 7. Hypocrea variabilis, n. sp. Fig. 6, part of a leaf with plants, natural size ; fig. 7, a plant magnified.

Fig. 8. Xylaria Kurziana, n. sp.

Fig. 9. Thelephora pusilla, n. sp.

Figs. 10 and 11. Xylaria mutabilis, n. sp. Plants in different states. In some of the specimens, notably in the large specimen on the right of fig. 11, fragments of brick remain attached to the bases of the plants. 
Polyports (Mesopts) Crassipes, n. sp. Pileo lignoso, infundibuliformi, fusco-purpureo, margine umbrino et zonato; stipite durissimo, badio, ad basin incrassato; poris minutissimis, stipite pallidioribus.-Yomah river, Pegu. There is no number to the specimen.

This plant resembles in some points $P$. parvulus and $P$. carbonarius, Fr., but differs widely in other respects. I do not know any species to which it can be referred.

Plate 19. fig. 13. Plants of the natural size.

P. (Pleuropus) sanguineus, Fr.

This common tropical species occurs in Mr. Kurz's collection from Mutlah, in Lower Bengal, No. 2031; from the Botanic Garden, Calcutta, No. 2682; and from Tongloo, Sikkim Himalaya, 5000-6000 feet, No. 2584.

P. (Pleuropus) modestus, Kunz, Fr. Linn. v. p. 519 ; Fr. Epicr. p. 444.-Yomah range, Northern Pegu, No. 2610.

This is the same species as $P$ cervino-nitens, Schweinitz.

P. (Pleuropus) flabelliformis, Kl., Fries, Epicr. p.444.-Yomah range, Pegu, No. 3491.

P. (Pleuropus) affinis, Fr. Epicr. p. 445.-Yomah range, Pegu, Nos. 2628 \& 3490.

Evergreen Forests, Bookee ridges, Karen country, 5000-6000 feet, No. 2617.

No. 2617 has a very short stem and an irregular margin, but I cannot make it out to be any other species.

P. (Pleuropus) Picipes, Fr. Epicr. p. 440.-Botanic Garden, Calcutta, No. 2655.

There is also a specimen from Sikkim without a number.

P. (Pleuropus) Lucidus, Fr. Epicr. p. 442.-Botanic Garden, Calcutta, No. 2684. The yellow form of the species.

P. (Pleuropus) amboinensis, Fr. Epicr. p. 442.-Karen country, Pegu, 4000 feet. No. 2636.

This is a very variable species, probably not distinct from $P$. lucidus, Fr.

P. (Pleuropus) Splitbergeri, Mont. Cent. ii. no. 83 ; Sylloge, p. 164. no. 522.-Nattoung Hills, Pegu, 6000-7000 feet. No. 2638.

Plate 19. figs. 2 and 3. Fig. 2, the under side of the plant; fig. 3, the upper side: natural size.

This Polyporus agrees almost to the letter with the description of P. Splitbergeri in the 'Sylloge,' although the character " contextu aureo-nitido" is hardly applicable to the present plant. In the figure the pileus appears zonate, but the apparent zones are rather imbrications produced by the successive growths of the pileus. In Polyporus Nilgheriensis, Mont. (Sylloge, p. 164. no. 523), a closely allied species, the pileus is described as "antice prole nova subimbricata," and this description is exactly applicable to the present specimen of $P$. Splitbergeri. This plant being stemless, it might be thought that it ought to be placed in the division Apus; but it clearly belongs to the "prolificans " division of Fries, as described in his ' Novæ Symbolæ Mycologicæ,' p. 161, in which division the stem is sometimes wanting.

P. (Pleuropds) Brunneo-Pictus, Berk., var.-Arracan, Kolodyne valley, on old wood. No. 2045.

Plate 19. figs. 11 and 12. Fig. 11, the under side; fig. 12, the upper side: natural size. 


\section{$2 \mathrm{BHL}$ Biodiversity Heritage Library}

Currey, Frederick. 1876. "V. On a Collection of Fungi made by Mr. Sulpiz Kurz, Curator of the Botanic Garden, Calcutta." Transactions of the Linnean Society of London, 2nd series: Botany 1, 119-131.

https://doi.org/10.1111/j.1095-8339.1880.tb00251.x.

View This Item Online: $\underline{\text { https://www.biodiversitylibrary.org/item/13681 }}$

DOI: https://doi.org/10.1111/j.1095-8339.1880.tb00251.x

Permalink: https://www.biodiversitylibrary.org/partpdf/246354

\section{Holding Institution}

Missouri Botanical Garden, Peter H. Raven Library

\section{Sponsored by}

Missouri Botanical Garden

\section{Copyright \& Reuse}

Copyright Status: Public domain. The BHL considers that this work is no longer under copyright protection.

This document was created from content at the Biodiversity Heritage Library, the world's largest open access digital library for biodiversity literature and archives. Visit BHL at https://www.biodiversitylibrary.org. 